\title{
The Journey of American Capitalism: From Stockholders to Stakeholders
}

\author{
Mark Ray Reavis \\ University of Central Oklahoma \\ David W. Orr
Texas A\&M University-Texarkana
}

The American practice of capitalism has been nothing short of dynamic. The struggle to find an acceptable method of 'the proper administration of wealth' has been a key issue since at least the days of Andrew Carnegie. In the early years of American industrialization, the focus was largely and legally on stockholder rights. This focus shifted somewhat towards the benefit of labor as unions gained power in the early $20^{\text {th }}$ century. Then, the stakeholder view began to take root and grow in the last half of the $20^{\text {th }}$ century. This view expanded the conversation of capitalists vs. labor to include other stakeholders. This research reviews history and literature on the journey of American capitalism and takes the additional step of addressing expectations of corporate governance changes in the near future and the impact millennials are likely to have on the journey.

Keywords: business roundtable, capitalism, millennials, stakeholder theory, stockholder theory

\section{INTRODUCTION}

This research focuses on the changes in general business practices and behavior in America. The authors bridge the gap between academic theory of stakeholders/stockholders and corporate governance practice by providing historical perspectives of these issues and offering perspectives of future expectations on the topic. The purpose of the public company form of organization, considerations of labor, and corporate governance issues are presented. The impacts millennials are likely to have on American capitalism are expected to be significant and are also addressed.

There is more than one way to approach the issue of changing business practices in America over the past 200 years or so. One way is to consider stockholder theory vs stakeholder theory and the extent to which businesses have moved from a stockholder centered purpose of the firm to a stakeholder centered purpose. Another way to view the issue is to consider capitalism vs. socialism and the extent to which America has modified its approach to capitalism. A third perspective is philosophical. A utilitarian philosophy focuses on the greatest good for the greatest number of people while a deontological philosophy focuses on the achievement of goals, without concern for the consequences. These perspectives illuminate the changes in business practices in America from the days of its gaining independence until today. 


\section{LITERATURE REVIEW}

This literature review describes various aspects of capitalism generally. This will serve to lay the foundation for discussing the journey of American capitalism over the past $200+$ years in the sections that follow.

\section{The Proper Administration of Wealth}

"The problem of our age is the proper administration of wealth" (Carnegie, 1889, p. 682). The problem Carnegie identified is the struggle between capitalists and labor, stockholders and stakeholders, public corporations and communities. The problem only exists because wealth exists. So, the critical questions are - where does wealth come from? Who is responsible for creating and distributing this wealth?

According to Karl Marx, there are three social products of capital and labor. These are constant capital, variable capital, and surplus value (Rousseas, 1979). Constant capital, according to Marx, consists of the physical and financial resources used in the processes of production. Importantly, constant capital does not create value, or wealth, but is only used in its creation. Variable capital is the wages paid by capitalists to labor; and "it is only labor...that has the power to create value" (Rousseas, 1979, p. 10). Labor's wages are limited to the minimum amount required for laborers to sustain themselves and their families. Yet, labor produces more than enough to pay their wages (Rousseas, 1979). This excess is the surplus value, or wealth, of which Carnegie wrote in 1889.

Whether the creation of wealth is described using Karl Marx's ideas or some other theoretical framework, the basic idea of wealth creation through the use of corporate labor is well known and understood. The next natural question then is - who is the wealth created for (Pfarrer, 2010)? This is where arguments about the purpose of the firm begin to take shape. As famously stated by Milton Friedman, the Social Responsibility of Business is to Increase its Profits (1970). With profit benefiting owners/shareholders, Friedman's idea is clearly a central tenant of stockholder theory proponents. This view dominated American corporate culture and governance practice from the days of the industrial revolution until somewhat recently.

On the other side are proponents of a stakeholder approach. They focus on benefits to labor above the minimum required to sustain themselves, as described by Marx, and benefits to others "affected by the achievement of a corporation's purpose" (Freeman, 1984, p. vi). These stakeholder proponents are seemingly everywhere in American society in 2021. They are seeking a higher minimum wage, diversity in the boardroom, increased corporate social responsibility, and higher corporate income taxes. As a result, America finds itself in 2021 struggling with the same problem identified by Andrew Carnegie over one hundred and thirty years ago; the proper administration of wealth.

\section{What Is Capitalism?}

Another perspective on the changes in business practices in America over the past 200 years or so is to consider the broader economic system adopted by America. America is, without significant debate, a capitalist nation. So, it is useful to consider the economic system in which businesses operate in America to appreciate the changes that have taken place.

The best way to view economic systems is to consider them on a continuum, not as absolutes (Dickie \& Rouner, 1986) (Seldon, 1990). Ultimately, there are two basic types of economic systems on this continuum. These are, of course, capitalism and socialism. Broadly defined, capitalism is an economic system driven by market forces (Dickie \& Rouner, 1986). Market participants are individuals, families, businesses, and potentially government, when it acts only as a price taker in the market. In capitalism's purest form, government does not interfere in the market. The market determines the allocation of resources. Pure capitalism is really only theoretical, no actual example in history is identifiable (Dickie \& Rounder, 1986).

Capitalism isn't just a broad market driven economic system. It is characterized by the inclusion of "private property rights, decentralized power and individual responsibility for human behavior" (Seldon, 1990, p. 4). Andrew Carnegie went even further. In his Gospel of Wealth, he discussed the opposing systems 
of communism and individualism. Carnegie's use of the words communism and individualism may be easily substituted for socialism and capitalism. Carnegie then, describes capitalism as "Individualism, Private Property (rights), the Law of Accumulation of Wealth, and the Law of Competition" (Kirkland, 1965, p. 18-19). With these descriptions of capitalism, a clearer understanding of it is possible. Broadly, it is a market driven system. But, when examined further, it is characterized on an individual level by wealth accumulation and competition.

Since economic systems exist on a continuum, it is useful to briefly describe the opposite end of this continuum to gain a better appreciation of capitalism. Socialism then, is an economic system characterized by political/social allocation of resources (Dickie \& Rouner, 1986). A socialist system is designed to benefit society broadly. Equality, not individualism, is a major characteristic. Private property rights are limited, if they exist at all. The accumulation of wealth is for the benefit of society, not the individual. Carnegie's Law of Competition morphs into the 'Law of Cooperation'.

\section{What Capitalism Is Not}

Capitalism can be even more fully understood by also considering what it is not, or does not. Foremost in this consideration is the foundational tenet that capitalism does not seek economic equality. Economic equality is in direct opposition to Carnegie's description of capitalism as 'Individualism, wealth accumulation, and competition' (Kirkland, 1965).

Capitalism is not without rules (Reich, 2015). Rules governing capitalism may be described as the rule of law or as ethical rules (expected and accepted behaviors). This recognition that capitalism is governed by rules is instructive when considering Friedman's idea that corporations should 'stay within the rules' as they seek to maximize profits (Friedman, 1970). But laws and expected/accepted behaviors change. Rules regarding "Private property, constraints on monopoly, contracts, bankruptcy, (etc., change with) circumstances...technology...(as) old solutions become outmoded" (Reich, 2015, P. 81-82). Ethical rules change as society changes. This is evidenced by the 2019 Business Roundtable announcement regarding the purpose of a corporation and by the increasing influence of millennials on American society/business (Business Roundtable, 2019)(Reavis, Tucci, \& St. Pierre, 2017)(Walker, 2019).

Capitalism is not immoral or corrupt (Reich, 2015)(Smith, 1990). Even Andrew Carnegie, while amassing vast wealth as a proponent of capitalism, wrote that surplus wealth acquired during a person's lifetime should ultimately benefit society. Carnegie further quoted John Wesley, the famous evangelical founder of Methodism in the 1700s, as stating, "Gain all you can by honest industry...Save all you can...(then) provide things needful for yourself, food, raiment, \& provide for...your household. If you then have an overplus do good to them that are of the household of faith. If there still be an overplus, do good to all men" (Smith, 1990, p. 47). Then again, there's Friedman's comment on staying within the rules. Nowhere are immoral or corrupt behavior espoused as a part of capitalism.

\section{Relative to Public Corporations and Large Private Enterprises}

Most of the literature on corporate social responsibility (CSR), and thus the purpose of the firm, focuses on larger corporations. Sole proprietorships and other small businesses are typically ignored (Friedman, 1970)(Mahdavi \& Moore, 2017). This is appropriate because the agency issues associated with stockholder theory and stakeholder theory, the framework within which CSR and the purpose of the firm are often addressed, are most relevant for larger companies. Though these companies are often public, larger private companies are not immune to stakeholder conflicts and agency problems (Ferrell, Thorne, \& Ferrell, 2016). The focus of this research is similar; considering changes in American business over the past 200 years or so as reflected by larger businesses' practices and ignoring small business issues.

\section{General Arguments for \& Against Capitalism}

This literature review would not be complete without a discussion of the arguments for and against capitalism. Certainly, there are very strong opinions on both sides.

Almost every discussion of capitalism includes at least an acknowledgement that its adoption as an economic system leads to a higher standard of living (Kirkland, 1965)(Moore, 2009)(Pack, 1991)(Seldon, 
1990)(Smith, 1990). Some go further than simply stating that the standard of living under capitalism is greater. Carnegie states that it had created "enormous improvements in the lives of everybody" (Smith, 1990, p. 45). Seldon (1990) states that capitalism creates "standards of living that are multiples of socialism, and combine them with liberties unknown in socialism" (p. 124.).

Capitalism spurs innovation (Smith, 1990). According to George W. Bush, it is the best system ever devised and it gives people the "freedom to choose where they work and what they do" (Moore, 2009). At the dawn of the machine age, Adam Smith favored capitalism because it lead to higher economic growth, increased demand for workers, and increased wages for workers; ultimately resulting in "material benefits to the common person" (Pack, 1991, P. 166).

These are strong arguments for capitalism and describe its virtues not only for society at large, but also for the individual. But, arguments against it are strong too. Chief among the arguments against capitalism is the inequality that results from it (Dickie \& Rouner, 1986)(Moore, 2009)(Walker, 2019). Descriptions of this inequality are severely negative.

Walker's (2019) derision of the inequality of capitalism is particularly useful here because it directly addresses capitalism in America in modern times. He describes American capitalism as having produced extreme and even unprecedented levels of inequality. He states that it is unfair and even unjust. Michael Moore's film Capitalism: A Love Story (2009) focuses squarely on his very negative view of capitalism in America. Moore (2009) describes capitalism as "a system of taking and giving, mostly taking". The position Moore takes in his work seems to be that every problem in American society is the result of its adoption of capitalism as an economic system.

The issue of inequality has also been described by Karl Marx as miseration. The theory is that inequality, within a society, leads to the creation of increasing misery of increasing numbers of people. Ultimately, miseration leads to revolution (Dickie \& Rouner, 1986).

Many other arguments exist against capitalism. Some state that capitalism creates inequality with other societies (consider America vs modern third world countries). It produces negative effects on the environment. It has the dehumanizing effects of producing greed and materialism. It exploits the nonwealthy (Dickie \& Rouner, 1986). This list is not exhaustive.

Now the foundation has been laid to discuss the American journey.

\section{THE JOURNEY FROM STOCKHOLDERS TO STAKEHOLDERS}

Keeping in mind that economic systems exist on a continuum is useful from this point forward, as the journey from stockholders to stakeholders is more about America moving along the continuum than it is about abandoning capitalism and adopting socialism. This movement along the continuum has been slow, stubborn, and difficult. In the late 1800s Andrew Carnegie described it like this, "...to change it...is not practicable...even if desirable theoretically" because it goes against human nature itself, as man is individualistic and competitive (Kirkland, 1965, p. 18). His perspective made good sense, at least for many of his contemporary readers, since America was settled largely by European immigrants seeking freedom and the ability to make their own livelihood, without noble oppression.

But that perspective is now well over 100 years old. Since then, much has changed. American demographics are different now. The rise of labor has created a powerful middle class. Millennials have burst into the mainstream of American society with very different views than previous generations on issues of income inequality, equality of opportunity, justice, corporate social responsibility, and the purpose of corporations in society (McGlone, Spain, \& McGlone, 2011)(Reavis, Tucci, \& St. Pierre, 2017)(Walker, 2019).

\section{Inequality and the Law}

Capitalism was the first organizational form to co-opt labor in mass production, and thereby harness the power of the masses (Rousseas, 1979). Several issues evolved from this relationship that are not in dispute. First, the ability of industrialists to mass produce anything was tied to, and dependent upon, labor (Rousseas, 1979)(White, 2008). 
Though bound together for mutual benefit, great inequality developed between industrialists/corporations and labor. Regarding this inequality, Carnegie not only recognized that it resulted from capitalism, he endorsed it. He specifically stated that "great inequality (is) not only beneficial, but essential to the future progress of the race" (Kirkland, 1965, p. 16-17).

This inequality led to inevitable conflicts between early industrialists and labor. A vivid example of this is the Homestead Strike. In 1892, laborers rioted in a violent dispute against the Carnegie Steel Company in an attempt to secure better wages and working conditions. During the riot and the aftermath, seven workers were killed. In spite of public support for labor, 8,500 soldiers of the Pennsylvania National Guard were sent to restore order and the steel plant reopened with replacement workers (Adamczyk, 2020).

With government siding openly and forcefully with business interests over labor, legal foundations began to be established to support capitalism. Viewing capitalism from a strictly legal perspective; society, through its laws, regulations, and standards, govern the behavior of private business. Business, therefore, is only required to act/behave withing the law (Dickie \& Rouner, 1986). As corporate law developed, it became clear that the function of a corporation was to enhance the interest of stockholders (Freeman, 1994).

Laws passed, and various court rulings over the next few decades following Homestead, strongly favored business and disfavored labor. The Sherman Anti-Trust Act was passed in 1890. The intent of the law was to limit/prevent monopolies. But, in 1903 a federal court in Connecticut ruled that it applied to unions. The court ruled that "labor unions, found guilty of combining to limit the market of goods transported from one state to another, were liable for the payment of three-fold damages" (White, 2008, p. 338). Consequently, this ruling, based on the Sherman Anti-Trust Act, threatened labor's most powerful weapon, the strike. The Clayton Act was passed in 1914 in an attempt to exempt labor unions from the Sherman Anti-Trust Act. But, "repeated judicial decisions have utterly riddled the labor clauses of the Clayton Act", diminishing its support of labor (White, 2008, p. 338).

Key to further legal developments was the establishment of the shareholder primacy norm (SPN). SPN rests on the ideas that "A business corporation is organized and carried on primarily for the profit of the shareholders" and "Corporate directors have a fiduciary duty to make decisions that are in the best interests of the shareholders" (Smith, 1998, p. 278). This was established with the Michigan Supreme Court ruling in 1919 in Dodge v. Ford (Copeland, 2019). In this famous case, Henry Ford argued that his intent was to operate Ford Motor Company "for the general purpose... to benefit mankind" (Copeland, 2019). The court ruled against Henry Ford and in doing so the SPN was established as fundamental to corporate law (Smith, 1998)(Smith \& Ronnegard, 2016). The SPN has evolved with the application of the business judgement rule. Basically, this rule holds that Directors are not liable for honest mistakes (Smith, 1998). Also, a court cannot substitute its own business judgement for that of a Board of Directors'. This "relieves the court from...evaluating the quality of business decisions" (Smith \& Ronnegard, 2016, p. 466).

But laws are made by human beings. Laws are not static. Laws regarding many issues essential to a capitalist system, such as private property, monopoly, contracts, labor, etc., continue to evolve (Reich, 2015).

\section{Focus on Labor}

Consider the legal oppression from which laborers fled Europe to come to America. In the late 1700s, laborers in England, "...were compelled by law to remain in the pits as long as the owner chose to keep them at work there, and were actually sold as part of the capital invested in the works. If they accepted an engagement elsewhere, their master could always have them fetched back and flogged as thieves for having attempted to rob him of their labor" (Kirkland, 1965, p. 93).

Before 1800, laborers began to organize in New York to protect their interests against merchant capitalists. By the mid-1830s, over 300,000 workers had joined local unions. In spite of this, working conditions before the Civil War remained bad. The workday was often 14-16 hours long. As much as forty percent of all workers in New England factories were between the ages of seven and sixteen. Children were often taken from orphanages to work in the factories. "There was no socialized protection against sickness, accidents, or unemployment" (White, 2008, p. 316). 
By the late 1800s in America, a labor revolution of sorts had occurred. Laborers had the right to bargain for their labor. They had achieved a significant level of freedom. However, that created its own friction in the relationship of labor and corporations/industrialists. In 1886, Carnegie wrote, "...there is unrest, showing that the equilibrium has not yet been reached between employers and employed" (Kirkland, 1965, p. 94). This was a significant foreshadowing of Homestead, discussed in the above section, which occurred six years later in 1892 (Adamczyk, 2020). Over the next few decades, the power of labor unions grew tremendously in America. By the 1950's, over 30 percent of America's private sector workforce was unionized (Reich, 2015).

Another key labor issue in America has been the establishment and expansion of minimum wage. A federal minimum wage of 25 cents/hour was established in 1938 when the Fair Labor Standards Act was signed by President Franklin Roosevelt. The original minimum wage amount applied to only a limited number of workers. The hourly rate has been increased and the types of workers covered also expanded 28 times from 1938-2019. The last federal increase in minimum wage occurred in July 2009. More recently, from 2017-2019, 23 individual states have increased their own minimum wage. Momentum is building for another federal increase (Reavis \& Reavis, 2020).

The "Golden Era" of the middle class in America occurred after WWII until roughly the late 1970s (Tankersley, 2020, p. 97). Many factors contributed to this era, but the greatest factor was the expansion of labor in the manufacturing/industrial sector (Reich, 2015)(Tankersley, 2020). But, the swell of benefits to labor that occurred as a result of the growth of labor unions, establishment of minimum wage jobs, and economic expansion after WWII shifted dramatically in the late 1970s.

One issue to consider is CEO pay. CEO pay circa 1965 was approximately 20 times the average worker. Around 2015, CEO pay had risen to approximately 300 times the average worker's pay (Reich, 2015). At the point of inflection of the American economy, approximately 1978, CEOs began to focus on efficiency as a method for maximizing Return on Equity. One effect was that CEO pay rose as their compensation was based on a firm's profitability and/or stock performance (Fischer, 2020)(Reich, 2020). The friction Carnegie wrote about in the late 1880s is still very relevant today. CEO pay is one illustration of that.

The larger issue was globalization. The quest for ever-greater efficiency was driven by globalization. In the late 1970s, America's economy pivoted from the 'Golden Era' of the middle-class to an economy of flat real wages over the next four decades (Reich, 2015)(Tankersley, 2020). The success of labor unions since WWII had brought about increases in wages and the standard of living for the middle-class. But, the low costs of labor abroad drew away American manufacturing jobs from the 1980s - about 2016. While the drive for ever-greater efficiency drove higher productivity, profits, and CEO pay, it concurrently failed to reward labor (Reich, 2015)(Tankersley, 2020). The friction that Carnegie identified between labor and employer over a hundred years ago was exacerbated by globalization and skyrocketing CEO pay. Equilibrium has still not been achieved.

\section{Considering Milton Friedman Along the Journey}

No consideration of American capitalism would be complete without some discussion of Milton Friedman's (1970) The Social Responsibility of Business is to Increase its Profits. In it, Friedman states, "...the doctrine of "social responsibility" involves the acceptance of the socialist view that political mechanisms, not market mechanisms, are the appropriate way to determine the allocation of scarce resources..." (1970). This clearly reflects the continuum upon which economic systems rest, as discussed above. Friedman rests firmly on the capitalist end of the continuum. His statement that "...a corporate executive's ... responsibility is to ... make as much money as possible... (for) the individuals that own the corporation" is as capitalist as possible (Friedman, 1970).

Debate continues on capitalism and whether or not it is moral or ethical (Pack, 1991). University students still study Friedman's work and often conclude that his view is immoral or unethical, or at least out-of-date (Reavis, et. al, 2017). These students are correct about Friedman's view being out-of-date.

Of particular interest is the timing of Friedman's work. It was published in 1970, squarely in the midst of the Golden Era of the middle class in America. Globalization had not yet robbed America of its economic 
glory. His view was a reflection of the past. Soon thereafter, America began to move away from Friedman and toward a stakeholder approach.

\section{Stakeholder View Development}

Before moving past Freidman, a glance backward is appropriate because several stakeholder arguments preceded Friedman's 1970 article. One of note is Chester Barnard's The Function of the Executive (1938). Barnard "argued that the purpose of the corporation was to serve society, and that the function of the executive was to instill this sense of moral purpose in the corporation's employees" (Freeman \& Dickie, 1986, p. 89). Given the Business Roundtable's statement in 2019 of the purpose of the firm, discussed below, it appears Barnard was ahead of his time, about 80 years.

Stronger stakeholder arguments began to grow in the late 1970s. In 1977, the Wharton School began a Stakeholder Project. Their first task was to define stakeholders. Two definitions emerged. First, "The Narrow Sense of Stakeholder: Any identifiable group or individual on which the organization is dependent for its continued survival" and second "The Wide Sense of Stakeholder: Any identifiable group or individual who can affect the achievement of the organization's objectives or who is affected by the achievement of the organization's objectives" (Freeman \& Reed, 1983, p. 91).

The Stakeholder movement began to blossom with Freeman and Reed's publication of Stockholder and Stakeholders: A New Perspective on Corporate Governance (1983). In their work, Freeman and Reed clearly define and describe stakeholder theory. They provide significant insights into a new corporate paradigm of corporate governance through a stakeholder approach. A year later, in 1984, Freeman published Management: A Stakeholder Approach. In this work Freeman provides extensive details on the role of the senior executive, implications for mid-level management, and the role of the board. He describes in great detail the framework and philosophy of a stakeholder management approach to corporate governance.

Many other scholars began to join Freeman in an effort to describe and nurture the stakeholder movement; indeed, reflecting an intent to replace the dominant version of American Capitalism. Edwin A Murray, Jr.'s work Ethics and Corporate Strategy focused on his observation that there existed a growing number of senior corporate executives who saw a connection between corporate strategy and ethics (Dickie \& Rounder, 1986). Murray addressed the topic philosophically. He describes the philosophy of utilitarianism as "the notion of the greatest good for the greatest number of people" and a contrasting philosophy of deontology as "the concept of duty to perform the good regardless of consequences" (Dickie $\&$ Rounder, 1986, p. 104-105). Murray surmises that corporations are more often guided by a deontological philosophy, emphasizing process and the achievement of results.

This philosophical framework aligns with the economic system continuum described above. Utilitarianism clearly aligns with socialism and with a stakeholder approach. Deontology clearly aligns with capitalism and a stockholder approach. Murray espouses a utilitarian approach. He states that stakeholders, as well as stockholders, "have important claims on a business" and "Regulatory agencies also have an interest in the performance of companies on behalf of the public at large" (Dickie \& Rounder, 1986, p. 109). Murray then removed any doubt that his view was in support of a more socialist economy when he stated, "Fundamentally, what the strategist must be concerned about is no longer simply the increasing of shareholder wealth but rather the more holistic objective of increasing the institution's contribution to society" (Dickie \& Rounder, 1986, p. 110). Murray describes what some of these contributions should be, including striving for social justice, addressing income inequality, high crime rates, and racial tension, etc.

The 1990s saw an attempt to reconcile stockholder and stakeholder views. The question - Whose wealth should be maximized? was addressed, along with an attempt to explain why it is important for firms to "recognize the value of the relationships the firm has with its major stakeholders" (Chang, 1997, p. 10). Of course there are two answers to the question. First, the stockholder/capitalist/deontological answer that wealth belongs to the stockholders. Second, the stakeholder/socialist/utilitarian answer that wealth belongs to society. Chang (1997) answered the question in a traditional capitalist fashion but recognized that stakeholder laws had been passed in 40 states in recent years to protect various parties and that there was 
growing support for the idea that corporations have a social responsibility. Chang (1997) reflects broad movement along the economic system continuum away from capitalism and towards socialism.

The 2000s brought bolder criticism of America's version of capitalism as the financial crisis plummeted the entire world into the Great Recession. In Capitalism: A Love Story (2009), Michael Moore identified a variety of extremely negative issues in American society. These were high levels of foreclosures, evictions, increased dependence on food stamps, and high unemployment. He strongly criticized the American system of capitalism and blamed the state of society on its failures. Moore's film was passionate. It reflected a popular view at the time that the American capitalist system was broken, and that corporate greed should be replaced with a system in which labor and society exert more control over corporate governance.

\section{Measures of Stakeholder Focused Organizations}

Stakeholder theory supporters argue that stakeholders are affected by the business' operations and thus the business is obligated to provide value to these various stakeholders. Some argue that providing value is at the expense of stockholder value (Rausch, 2011). Others argue that the stakeholder approach generates, or adds to, value (Sustainalytics, 2019). Measuring the results of a stakeholder approach then becomes an important issue to consider. The variety of measures and the acknowledgement of the vast number of people and companies that are focused on these measures is further evidence of the movement along the economic system continuum toward a stakeholder approach.

The balanced scorecard approach is one method of quantifying the results of business decisions in various identified areas in a semi-holistic approach. The scorecard is a planning and management tool to align activities with organizational goals and missions. The Balanced Scorecard Institute (BSI) helps organizations with developing the scorecard. BSI developed a scorecard framework organized around four core components: Customers/Stakeholders, Financial/Stewardship, Internal Processes, and Organizational Capacity. Under the BSI model, the organization develops Key Performance Indicators in the areas aligning to the four core components. The scorecard is then used organization-wide to determine if certain goals are being met using the holistic approach of the core areas. The scorecard is about providing feedback to the executive team to more closely associate actions with goals (Balanced Scorecard Institute, 2020)(Cokins, 2013).

The Triple Bottom Line (TBL), is another approach. TBL was mainstreamed by John Elkington's book (1997) Cannibals with Forks: The Triple Bottom Line of 21st Century Business. The concept is simple; along with the Profit-making operational decisions of a company, there are two other operational areas to address: People and Planet, also known as 3P. The key aspect is the sustainability of the business through performance in financial, social, and environmental areas (Slaper \& Hall, 2011).

In September 2018, Sustainalytics launched a new version of its Environmental, Social, and Governance (ESG) rating. This new ESG rating "Reflects the degree to which a company's enterprise value is exposed to Material ESG Issues (MEIs)" (Sustainalytics, 2020). The new ESG rating was developed in response to a large number of investors' desires to invest according to the Principles of Responsible Investment. The Principles for Responsible Investment focuses on ESG issues (Principles for Responsible Investment, 2020). Sustainalytics indicates that over $25 \%$ of global investment funds have expressed a desire to consider ESG ratings when making investment decisions. Their new ESG rating considers management and measures of risk related to 20 ESG issues. Some of these issues are Community Relations, Business Ethics, Occupational Health and Safety, and Resource Use Emissions. Sustainalytics' data indicate a significantly higher return on investment for investors who choose to invest in companies with ESG ratings in the top quintile (Sustainalytics, 2020).

A Certified B Corp is a company that has been certified by the independent, non-profit organization B $\mathrm{Lab}$ that co-founded in 2006 by three entrepreneurs. Their mission was to create a corporate entity that both maximized wealth and positively impact society and the environment. B Lab established a set of guidelines for businesses certification through a 4-step process. The first-step is to describe their public benefit they are pursuing, such as unemployment, nutrition, education, etc. The second step is to assess their overall social and environmental impact using an accepted third-party standard for their industry. The third step is to identify the company officer(s) who will ensure the company follows its stated goals. The designated 
officer must consider the company's impact on (i) the stockholders; (ii) the employees; (iii) customers; (iv) communities; (v) the local and global environment; (vi) the short-term and long-term interests of the benefit corporation, and (vii) the ability of the benefit corporation to accomplish its general public benefit purpose and any specific public benefit purpose. In the fourth step, the company must name every person who owns more than five percent of the company. The benefits of B Lab certification include greater stockholder rights, reduction in director liability, access to increased private capital investment opportunities, greater and faster investor access while preserving the company's mission, attracting talent, a reputation for leadership, and a promise of what future Fortune 500 companies look like (B Lab, 2017). A study in 2015 of the forty-five original B-Corps companies found that all made progress toward their stated goals, were profitable, and had published annual reports with greater transparency (Wilburn \& Wilburn, 2015).

One of B-Lab's first projects was to develop a legislative model for states that decide to add the Benefit Corporation as a new business entity type to their state's laws. Businesses can initially choose to form as a Benefit Corporation or may convert to this entity type, subject to states' restrictions. As of 2019, thirtyseven states and the District of Columbia have enacted Benefit Corporation legislation (Benefit Corporation, 2021). This legally allows the company to deliberately focus resources on a self-identified social benefit/cause and operate in a manner that does not require it to pursue maximization of stockholder wealth. It goes beyond measuring stakeholder impact to a governmental acknowledgement and approval of the firm's stakeholder focus.

\section{Millennials as Stakeholders}

A brief recap of the past few decades is useful here. In the 1970 s, some significant recognition of stakeholder issues began to emerge. The movement grew in the 1980s with the development of a stakeholder perspective on corporate governance. This was followed by much debate and the establishment of stakeholder governance measures of performance in the 1990s. Since 2000, a variety of measures have emerged that focus on firms' stakeholder related behaviors. This brief summary of stakeholder development since the 1970s illustrates the growing momentum of stakeholder centric governance in American corporations and the significant movement along the economic system continuum.

Millennials will continue to move America along the continuum. Millennials are the generation born in approximately 1980-2000. Publications describe the years of birth with some variation, but the early 1980 s - around 2000 is common (McGlone, et.al., 2011). Nearly 78 million babies were born in America from 1980-2000. More Millennials were born than GenXers (1965-197), Boomers (1946-1964), or the Silent Generation (1925-1945) (Rainer \& Rainer, 2011). Millennials surpassed the declining Boomers in the labor force in 2013. Then "Millennials Became the Largest Generation in the Labor Force in 2016" by surpassing the GenXers (Arkansas Business, 2018).

Rainer \& Rainer (2011) describe Millennials' philosophy about wealth, fame, and power as a "means to a greater good (rather) than an end in and of itself" (p. 17). This philosophy seems to be in stark contrast to the writings of Andrew Carnegie in 1889 when he wrote, "the accumulation of wealth, and the Law of Competition ... are ... the best and most valuable of all that humanity has yet accomplished" (Kirkland, 1965, p. 19).

Voluminous writings describe Millennials and their attitudes towards work and society. Some have described this generation as lazy, entitled, and even narcissistic (Howe \& Strauss, 2000)(Roker, 2017)(Sharp, 2014). But, there are many more voices describing them in positive ways. "Three out of four Millennials believe it is their role in life to serve others" (Rainer \& Rainer, 2011, p. 37). Millennials are motivated to make a positive difference in society. They are highly inclusive, seek to work in teams, and are skilled in the use of technology (Keszie, Murphy, \& Loeur, 2018).

Millennials' primary issue in their decision to be in the labor force is work/life balance (Rainer \& Rainer, 2011). Millennials want to work for companies that make a positive impact on society. "Millennials actually do intend to reward or punish a company based on its commitment to social causes" (McGlone, et.al., p. 196). Working for companies that are committed to stakeholder governance gives their lives meaning (Sharp, 2014). 
The philosophy and sheer size of this generation will impact America's economic system. "They are likely to change the corporate culture as they move into positions of senior management" (Reavis \& Tucci, 2020, p. 126). "Women will win rising shares of leadership positions" (Howe \& Strauss, 2000, p. 312). "Boomers' all-encompassing greed" will be replaced by Millennials' altruism (Sharp, 2014). "The Millennial future is what America is destined to become" (Howe \& Strauss, 2000, p. 366).

\section{The Business Roundtable}

The Business Roundtable is "An Association of Chief Executive Officers Committed to Improving Public Policy" (Business Roundtable, 1997). This group of CEOs meets periodically to discuss, and publish statements on, issues affecting public policy and private enterprise. Since 1978, the Business Roundtable has periodically issued statements on Principles of Corporate Governance. In 1997, before any Millennial reached the age of majority, the Business Roundtable issued a significant statement on Corporate Governance. The first sentence of the 1997 statement is, "the Business Roundtable wishes to emphasize that the principal objective of a business enterprise is to generate economic returns to its owners" (Business Roundtable, 1997). Also in their 1997 statement, they addressed the question of - should corporations be managed purely in the interests of stockholders or take into account the interests of stakeholders as well? Though this question is considered, the Business Roundtable provides a bold response to the question, "In the Business Roundtable's view, the paramount duty of management and of boards of directors is to the corporation's stockholders" (Business Roundtable, 1997).

In August 2019, a shift occurred. A new statement on the purpose of a corporation was issued. This new statement was signed by 181 of the 193 members of the Business Roundtable (Copeland, 2019). Here is a limited list of the companies whose CEOs signed the 2019 statement: Abbott, Amazon, American Airlines, American Express, Apple, AT\&T, Bank of America, Blackrock, Coca-Cola, Exxon-Mobil, FedEx, General Motors, Pepsi, Target, UPS, \& Walmart (Business Roundtable, 2019a). These companies represent many of the largest and most influential in America and are also some of the largest employers. The first sentence of the new 2019 statement is strikingly different than the 1997 statement. It states, "Americans deserve an economy that allows each person to succeed through hard work and creativity and to lead a life of meaning and dignity" (Business Roundtable, 2019a). The 2019 statement communicates "a fundamental commitment to all of our stakeholders" (Business Roundtable, 2019a). Rather than focusing on stockholders, the 2019 statement lists specific stakeholders and the signing CEOs commitment to them, in this order (all caps added for emphasis):

- Delivering value to our CUSTOMERS.

- Investing in our EMPLOYEES.

- Dealing fairly and ethically with our SUPPLIERS.

- Supporting the COMMUNITIES in which we work.

- (and finally) Generating long-term value for SHAREHOLDERS.

The statement may be viewed as revolutionary, but a more accurate understanding of it is that it simply reflects the times and attitudes of society (Copeland, 2019). It affirmed the role corporations play in society. It reflects the commitment of corporations "to push for an economy that serves all Americans" (Business Roundtable, 2019b).

The Business Roundtable website, https://www.businessroundtable.org today reflects a stakeholder/utilitarian view of American business and society. There are calls for leadership to foster economic security for employees, Policy Perspective statements on a variety of issues that support such things as an increase in the federal minimum wage, and THE LATEST information that communicates the Business Roundtable's efforts to support various, generally more socialist/utilitarian, public policies (Business Roundtable, 2021). Copeland (2019) makes a fair argument that the statements of the Business Roundtable are simply a reflection of American society. But the movement away from a more capitalist economy as recently as Friedman (1970) are revolutionary - even if the revolution has taken some 50 years. 


\section{Changes in Organizational Leadership}

As the understanding of business stakeholder issues has evolved over the last several decades, so has the discussion involving organization leadership. Chang (1997) discussed alternative views to the traditional concept of shareholders' wealth maximization (SWM) as the ultimate goal of the firm that were emerging at the time. The survey found that as corporate management was becoming more diverse, multifunctional and cross-cultural the alternative ideas of SWM needed further study.

Similar findings were discussed in a Harvard Business Review article detailing the pathways to C-Suite management as defined the seven high level management positions in a company including CIO, chief marketing and sales officer, CFO, general counsel, chief supply-chain-management officer, chief human resource officer, and CEO. A salient theme throughout the new set of skills requirements for C-Suite positions includes strong communication, empathy, collaboration, and trust building. In particular for the CEO, one skill noted at the forefront will be "the ability to elicit public trust as the face of the company... including credibility with socially responsible initiatives" (Groysberg, Kelly \& MacDonald, 2011).

Even Peter Drucker, who is widely regarded as one of the most influential management researchers of the past century, discussed the expectations of corporate governance changes. According to Drucker, "Leaders in every single institution and in every single sector ... have two responsibilities. They are responsible and accountable for the performance of their institutions, and that requires them and their institutions to be concentrated, focused, limited. They are responsible also, however, for the community as a whole" (Hesselbein, 2010). Furthermore, in many of Drucker's writings he encouraged business leaders to view the community as a responsibility of the corporation not mutually exclusive. He called on corporate leaders to embody "the Spirit of Performance" by exhibiting high levels of integrity in their moral and ethical conduct, focusing on results, building on strengths and leading beyond borders to meet the requirements of stakeholders, ultimately serving the common good (Hesselbein, 2010).

\section{Public Policy Implications}

Public policy discussions, as it relates to expectations of corporate governance changes, have focused on the promotion of corporate social responsibility (CSR) globally. While private sector CSR efforts have varied, governments have become increasingly proactive in promoting corporate social responsibility through public policy initiatives. Over time, governments have sought more involvement in the private sector after the global financial crisis and, most recently, as economies emerge from the COVID-19 pandemic.

A 2009 study by Ascoli \& Benzaken explored CSR public policy initiatives in seven different countries: Brazil, Canada, China, Mexico, Peru, Sweden, and the United Kingdom. The particular countries were selected due to the variety of public policy within CSR and the countries represented varied stages of economic development. The study concluded three primary trends that spanned each of the countries studied including voluntary guidelines or binding standards that guide or require companies to implement socially responsible practices, national awareness campaigns and government funds made available for implementation of private sector CSR programs (Ascoli \& Benzaken, 2009).

Furthermore, the research found that the majority of the governments studied engaged in some type of promotion of CSR within the country's private sector including direct public policy examples in Brazil, Canada, and China (Ascoli \& Benzaken, 2009). According to Ascoli \& Benzaken, while the efforts were led by different agencies in each country, they all sought to promote CSR as a means to increasing trade and competitiveness. Even on a regional level, cities like Shenzhen, China have taken steps to encourage corporate social responsibility as a way for the city to retain its competitive advantage (Ascoli \& Benzaken, 2009). However, government-led CSR promotion faces several challenges with the primary issue being efforts to promote voluntary actions do not guarantee implementation. Furthermore, a 2011 study found that CSR practices fail to influence business practice and become part of the firm's everyday activities. The results revealed that the adoption of CSR practices by firms is rather driven by competitive and legitimacy reasons than from a sheer interest on behalf of the firm to integrate CSR practices in its operations (Iatridis, 2011). Additionally, of the countries referenced in the Ascoli and Benzaken study there are few impact assessments or quantitative evidence demonstrating that CSR activities can lead to increased trade and 
competitiveness. As a result, without empirical evidence, the study found "it is difficult to make voluntary actions attractive to businesses, especially in times of economic hardship" (Ascoli \& Benzaken, 2009).

In addition to the measures discussed above, there have been other international efforts to quantify and benchmark CSR standards that may influence future public policy considerations. Namely the Organization for Economic Cooperation and Development (OCED) Guidelines for Multinational Enterprises, the United Nations Guiding Principles on Business and Human Rights, and the International Organization for Standardization (ISO) 26000 on Social Responsibility to name a few. While these efforts have progressed the CSR conversation internationally, more research is needed on the relationship of CSR public policy initiatives and their impact on the private sector.

\section{Expectations of Future Issues}

Chester Barnard (1938) argued that the purpose of the corporation was to serve society. He might be pleased today to see that American business has moved significantly toward his stated purpose. Indeed, there are many examples of more movement towards a stakeholder driven corporate culture in just the past few years that could pull America further away from a stockholder driven corporate culture toward a stakeholder driven corporate governance. One interesting example is a new law in California that requires diversity on the board of directors for public companies. This law, Assembly Bill 979, was signed by Governor Gavin Newsom in September 2020 and requires that a public company with its principle offices in California must have at least one director from an underrepresented community by the end of 2021. If the board has nine or more members, it must have a minimum of three persons on the board from underrepresented communities by the end of 2022. AB 979 defines "director from an underrepresented community (as) an individual who self-identifies as Black, African American, Hispanic, Latino, Asian, Pacific Islander, Native American, Native Hawaiian, or Alaska Native, or who self-identifies as gay, lesbian, bisexual, or transgender" (Thomas \& Frenzen, 2021). This is just one example from within America of a recent law established to force corporations to serve society.

Another example of what the future may hold comes from India. In 2013, India passed an amendment to its Companies Act. The amendment required qualifying companies to spend at least $2 \%$ of their average net profit on Corporate Social Responsibility (CSR) activities (Hiralal, 2015). By 2018, Indian companies were contributing $\$ 1$ billion to CSR activities. This may in part be to the monetary penalties and potential imprisonment for failure to comply. The law is generating corporate support for education, poverty, gender equality, and hunger (Shira, 2020).

Europeans have interesting laws of codetermination. These laws require that public companies, and certain other public sector employers, have a percentage of directors that represent labor. The laws vary from country to country. Codetermination in Germany arose through collective bargaining agreements dating back to around 1918 (McGaughey, 2015). More recently in Germany, "codetermination has been the law of the land since 1976: Large corporations there have to allow half of their supervisory boards of directors to be elected by workers" (Walker, 2019). The purposes are to find ways to make capitalism fairer, to unlock the productive power of capitalism for better outcomes for mankind (Walker, 2019). Twenty countries had some form of codetermination law in Europe as of 2015. There were approximately 62.1 million workers in the public sector and 87.4 million in the private sector covered by codetermination laws (McGaughey, 2015).

These are only examples of possible methods that could be adopted broadly in America that could lead America towards a more stakeholder driven economy. In the weeks before the 2020 presidential election, Joe Biden embraced 'stakeholder capitalism'. The idea would be to replace the outdated notion that corporations exist for the benefit of their shareholders with a new and greater focus on stakeholders (Stuttaford, 2020). Stuttaford (2020) calls this 'corporatism' and states that this is "based on the belief that society should be organized by and for its principal interest groups - let's call them "stakeholders"". Stuttaford (2020) rightfully points out one of the challenges with corporatism. That is - how is success measured? What social objectives or environmental objectives should a company address? Measuring success related to stakeholder issues is addressed in the Measures For Stakeholder Focused Organizations above. But which would be acceptable? Should government intervene and establish a law like India's 
Companies Act? Should government require boards to be constituted in certain ways like California or Europe? These are only some of the possible questions to be answered in the near future.

\section{SUMMARY AND CONCLUSIONS}

Economic systems are not absolute, they are relative. There is socialism in capitalism and there is capitalism in socialism (Seldon, 1990). In America, it is clear that there is more socialism now than at any time in its history.

In the early days of American industrialization, capitalists were almost kings. Laborers struggled in deplorable and dangerous conditions working long hours with little pay and little sympathy from capitalists or government (Kirkland, 1965). Unions did much to improve workers' plight in the first half of the $20^{\text {th }}$ century(Reich, 2015). Then, in the last couple of decades of the $20^{\text {th }}$ century, a shift occurred. The economy, and society, shifted towards a stakeholder/utopian/socialist system (Freeman, 1994). This has caused American public companies to reconsider their raison d'être (Business Roundtable, 2019a).

Leaders must now consider not only profit, but also their communities (Business Roundtable, 2019a) (Business Roundtable, 2019b) (Hesselbein, 2010). Millennials' philosophy and behavior are already influencing America with preferences towards corporate social responsibility and stakeholder value driven decision-making (Reavis, et al, 2017)(Reavis \& Tucci, 2020).

America cannot operate in a bubble. The effects of globalization and international public policies will likely influence American policy and change the way corporations do business (Ascoli \& Benzaken, 2009)(Walker, 2019).

It is clear that America has clearly moved a great distance along the economic continuum since the days of Andrew Carnegie. The future is uncertain, but America appears to be moving at a more rapid pace than ever away from pure capitalism and towards a stakeholder driven economy. "The way forward is a new human-centered version of capitalism" (Yang, 2020).

\section{REFERENCES}

Adamczyk, J. (2020). Homestead Strike. Encyclopedia Britannica. Retrieved from https://www.britannica.com/event/Homestead-Strike

Arkansas Business. (2018). Millennials Constitute 35\% of U.S. Labor Force. Retrieved from https://www.arkansasbusiness.com/article/122227/millennials-constitute-35-percent-of-us-laborforce

Ascoli, K., \& Benzaken, T. (2009). Public policy and the promotion of corporate social responsibility. Business for Social Responsibility. Retrieved from https://www.bsr.org/reports/Public_Policy_Promotion_of_CSR.pdf

B Lab. (2017). B Corporation. Retrieved from www.bcorporation.net

Balanced Scorecard Institute. (2020). Balanced Scorecard Basics. Retrieved from https://balancedscorecard.org/bsc-basics-overview/

Barnard, C. (1938). The Function of the Executive. Harvard University Press. Cambridge, MA.

Benefit Corporation. (2021). Retrieved from http://benefitcorp.net

Business Roundtable. (1997). Statement on Corporate Governance. Retrieved from https://cdn.theconversation.com/static_files/files/693/Statement_on_Corporate_Governance_Busi ness-Roundtable-1997\%281\%29.pdf?1566830902

Business Roundtable. (2019a). Statement on the Purpose of a Corporation. Retrieved from https:/opportunity.businessroundtable.org/wp-content/uploads/2019/08/BRT-Statement-on-thePurpose-of-a-Corporation-with-Signatures.pdf

Business Roundtable. (2019b). Corporate Governance. Retrieved from https://www.businessroundtable.org/business-roundtable-redefines-the-purpose-of-a-corporationto-promote-an-economy-that-serves-all-americans

Business Roundtable. (2021). Leadership In Action. Retrieved from https://businessroundtable.org/ 
Carnegie, A. (1889). Wealth. North American Review, pp. 653-664.

Chang, S.J. (1997). Whose Wealth to Maximize: A Survey of Alternative Views on Corporate Objective. Journal of Financial Education, 23, 1-13. Retrieved from www.jstor.org/stable/41948258

Cokins, G. (2013). Kite with a Broken String - The Balanced Scorecard. Balanced Scorecard Institute. Retrieved from http://www.balancedscorecard.org/Resources/Articles-White-Papers

Copeland, J.R. (2019). The Business Roundtable's statement isn't revolutionary. It's a truism. The Washington Post. Retrieved from https://www.washingtonpost.com/opinions/2019/08/22/business-roundtables-statement-isntrevolutionary-its-truism/

Dickie, R.B., \& Rouner, L.S. (1986). Corporations and the Common Good. Notre Dame, IN: University of Notre Dame Press.

Elkington, J. (1997). Cannibals with Forks: The Triple Bottom Line of the $21^{\text {st }}$ Century Business. Gabriola Island, BC: New Society Publishers.

Ferrell, O.C., Thorne, D., \& Ferrell, L. (2016). Business and Society: A Strategic Approach to Social Responsibility \& Ethics. Chicago, IL: Chicago Business Press.

Fischer, M., \& Lindermoyer, J. (2020). Dodd Frank Act: Reporting CEO Compensation Relationship to Worker Ratio and Firm Performance. American Journal of Management, 20(1), 31-45. https://doi.org/10.33423/ajm.v20i1.2751

Freeman, R.E., \& Reed, D.L. (1983). Stockholders and Stakeholders: A New Perspective on Corporate Governance. California Management Review, 25(000003), 88-106.

Freeman, R.E. (1984). Strategic Management: A Stakeholder Approach. Boston, MA: Pitman.

Freeman, R.E. (1994). The Politics of Stakeholder Theory: Some Future Directions. Business Ethics Quarterly, 4(4), 409-421.

Friedman, M. (1970). The Social Responsibility of Business is to Increase its Profits. The New York Times Magazine. New York, NY: The New York Times Company.

Groysberg, B., Kelly, L.K., \& MacDonald, B. (2011). The new path to the C-suite. Harvard Business Review, 89(3), 60-68.

Hesselbein, F. (2010). How did Peter Drucker see corporate responsibility. Harvard Business Review.

Hiralal, M. (2015). India: Corporate Social Responsibility - Indian Companies Act 2013. Retrieved from http://www.mondaq.com/india/x/366528/Corporate+Governance/Corporate+Social+Responsibilit $\mathrm{y}+$ Indian+Companies + Act +2013

Howe, N., \& Strauss, W. (2000). Millennials Rising. New York: Vintage Books.

Iatridis, K. (2011). The influence of corporate social responsibility on business practice: The case of international certifiable management standards. (Doctoral dissertation). University of Central Lancashire.

Keszie, D., Murphy, K., \& Loeur, N. (2018). An Evaluation of American Millennials Leading Global Teams: A Multidimensional Framework for Planning and Optimizing Success. Journal of Management Policy and Practice, 19(1), 10-16.

Kirkland, E.C. (Ed.). (1965). The Gospel of Wealth and Other Timely Essays. Cambridge, MA: The Belknap Press of Harvard University Press.

Mahdavi, I., \& Moore, G. (2017). There is so little research done on small business corporate social responsibility. Why? Journal of Academic and Business Ethics, 10.

McGauhey, E. (2015). The Codermination Bargains: The History of German Corporate and Labour Law. LSE Law, Society and Economy Working Papers. London School of Economics and Political Science Law Department. Retrieved from file://C:/Users/mreavis1/Downloads/SSRNid2579932.pdf

McGlone, T., Spain, J.W., \& McGlone, V. (2011). Corporate Social Responsibility and the Millennials. Journal of Education for Business, 86(4), 195-200. https://doi: 10.1080/08832323.2010.502912

Moore, M. (2009. Capitalism: A Love Story. United States of America: Overture Films.

Pack, S.J. (1991). Capitalism as a Moral System. Brookfield, VT: Edward Elgar Publishing Company. 
Pfarrer, M.D. (2010). What is the Purpose of the Firm? Shareholder and Stakeholder Theories. In Good Business: Exercising Effective and Ethical Leadership (pp. 86-93). New York, NY: Routledge.

Principles for Responsible Investment. (2020). Sustainability Issues. Retrieved from https://www.unpri.org/pri/about-the-pri

Rainer, T.S., \& Rainer, J.W. (2011). The Millennials: Connecting to America's Largest Generation. Nashville, TN: B\&H Publishing Group.

Rausch, A. (2011). Reconstruction of decision-making behavior in stockholder and stakeholder theory: Implications for management accounting systems. Review of Managerial Science, 5(2-3), 137169.

Reavis, M.R., \& Reavis, D. (2020). The Impacts of a Voter Approved Minimum Wage in Arkansas. Journal of Business, Economics and Technology, 23(1), 80-94. Retrieved from http://nabet.us/j_archives/JBET_2020.pdf

Reavis, M.R., \& Tucci, J.E. (2020). Sustainability Effort Acceleration as Measured by Increased Propensity of Corporate Social Responsibility. Journal of Management and Sustainability, 10(2), 121-134. Retrieved from https://doi.org/10.5539/jms.v10n2p121

Reavis, M.R., Tucci, J.E., \& St. Pierre, G. (2017). Corporate Social Responsibility and Millennials' Stakeholder Approach. Journal of Leadership, Accountability and Ethics, 14(4), 74-83.

Reich, R.B. (2015). Saving Capitalism for the Many, Not the Few. New York, NY: Alfred A. Knopf.

Roker, A. (2017). Millennial Misconceptions - How They are Changing the Workplace. TODAY. New York City, NY: National Broadcast Corporation.

Rousseas, S. (1979). Capitalism and Catastrophe. New York, NY: Cambridge University Press.

Schwartz, M.S., \& Saiia, D. (2012). Should First Go "Beyond Profits"? Milton Friedman versus Broad CSR. Business and Society Review, 117(1), 1-31.

Seldon, A. (1990). Capitalism. Cambridge, MA: Basil Blackwell, Inc.

Sharp, K. (2014). Millennials' bold new business plan: Corporations with a conscience. Retrieved from http://www.salon.com/2014/02/09/millennials_bold_new_business_plan_corporations_with_a_co nscience/

Shira, D., \& Associates. (2020). Corporate Social Responsibility in India. India Briefing. Retrieved from https://www.india-briefing.com/news/corporate-social-responsibility-india-5511.html/

Slaper, T., \& Hall, T. (2011). The Triple Bottom Line: What Is It and How Does It Work? Indiana Business Review, 86(1).

Smith, D. (1990). Capitalist Democracy on Trial. New York, NY: Routledge.

Smith, N.C., \& Ronnegard, D. (2016). Shareholder Primacy, Corporate Social Responsibility, and the Role of Business Schools. Journal of Business Ethics, 134, 463-478.

Stuttaford, A. (2020). The Dangers of 'Stakeholder Capitalism'. National Review. Retrieved from https://www.nationalreview.com/2020/08/stakeholder-capitalism-corporate-money-power-servepolitical-agenda/

Sustainalytics. (2019). Understanding Sustainalytics' ESG Risk Ratings, WEBINAR. Retrieved from https://www.sustainalytics.com/sustainable-finance/2019/04/26/webinar-understanding-esg-riskratings- $2 /$

Tankersley, J. (2020). The Riches of this Land. Hachette Book Group. New York, NY.

Thomas, M., \& Frenzen, A. (2021). AB 979 Requires California-Based Publicly Held Corporations to Diversity Their Boards of Directors. The National Law Review, 21(77). Retrieved from https://www.natlawreview.com/article/ab-979-requires-california-based-publicly-heldcorporations-to-diversify-their

Walker, D. (2019). Saving Capitalism from Itself. Fast Company, (236), 48-92.

White, L.A. (2008). Modern Capitalist Culture. Walnut Creek, CA: Left Coast Press, Inc.

Wilburn, K., \& Wilburn, R. (2015). Evaluating CSR Accomplishments of Founding Certified B Corps. Journal of Global Responsibility, 6(2), 262-280.

Yang, A. (2020). The Democratic Debate. ABC News. St. Anselm College. New Hampshire, USA. 